\title{
Mortgage lending as a mechanism to stimulate investment demand in the context of digitalization
}

\author{
Tatiana Kolmykova ${ }^{1, *}$, Elvira Sitnikova ${ }^{1}$, Petr Kovalev ${ }^{2}$ and Elena Astapenko ${ }^{3}$ \\ ${ }^{1}$ Southwest State University, 94, 50 Let Oktyabrya st., Kursk, 305040, Russia \\ ${ }^{2}$ Central Research Institute "Cyclone", 77, Schelkovskoe shosse, Moscow, 107207, Russia \\ ${ }^{3}$ Yugra State University, 16, Chekhova str., Khanty-Mansiysk, 628011, Russia
}

\begin{abstract}
Currently, in difficult epidemiological conditions, there are significant changes in all spheres of human life. Also, the negative impact of the coronavirus epidemic (COVID-19) was not spared by such a significant area for humanity as a mortgage. Mortgage activity has undergone significant changes in the context of the pandemic, especially under the influence of negative factors. However, despite the difficult epidemiological conditions, the Government of the Russian Federation proposed supportive measures and provided assistance to citizens who found themselves in a difficult situation. The article analyzes the trend in the development of mortgage lending, determines the dynamics of the volume of housing mortgage lending provided by credit institutions to individuals, reveals the interdependence between the number of loans issued and the mortgage rate, examines the impact of overdue debt on mortgage loans on the efficiency of a credit institution. The article examines the activities of the leader in mortgage lending Sberbank. The authors proposed measures to improve the efficiency of mortgage lending development in the activities of Sberbank.
\end{abstract}

\section{Introduction}

Mortgage lending provides a solution to the most important problem in Russia - to acquire their own housing for the population. The use of this mechanism allows interested parties to achieve their goals - the bank to receive income, the client to purchase housing at the expense of credit funds, which the bank transfers to the developer's account (if it is an object of the primary housing market) or to the seller's account (if it is an object of the secondary housing market). Currently, Russian banks pay great attention to mortgage lending, due to the fact that mortgage is the main factor in the development of banking activities. However, economic instability creates the conditions for the need to constantly adjust the terms of mortgage lending, which makes it important to constantly monitor this market segment [1-4].

\footnotetext{
*Corresponding author: t_kolmykova@mail.ru
} 
The economic crisis of 1998 left a strong negative effect on the activity of mortgage lending, in connection with which a huge number of commercial banks ceased their activities [5]. Only since 2000 this segment of banking activity began to bounce back. In 2009 , only large commercial banks continued to operate in the mortgage lending market, tightening the conditions for issuing mortgage loans. 2010 can be considered a period of gradual recovery in mortgage lending, and since 2014 it has become the most important banking service. Based on the data of the Central Bank of the Russian Federation, the authors the authors have drawn up Figures 1 and 2 [9].

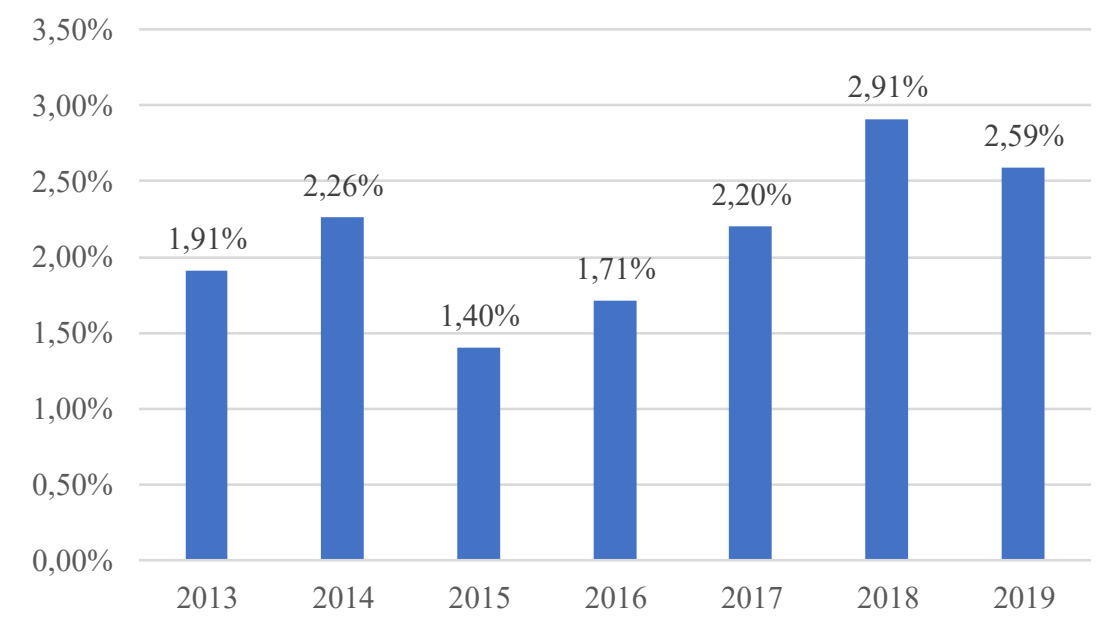

Fig. 1. Share of provided mortgage loans in gross domestic product of the Russian Federation, \%.

In 2015, the share of the volume of provided mortgage loans in GDP almost halved compared to 2014 , but since 2017 this indicator has grown from $1.40 \%$ to $2.91 \%$ in 2018 . The share of the volume of provided mortgage loans in GDP decreased by $0.32 \%$.

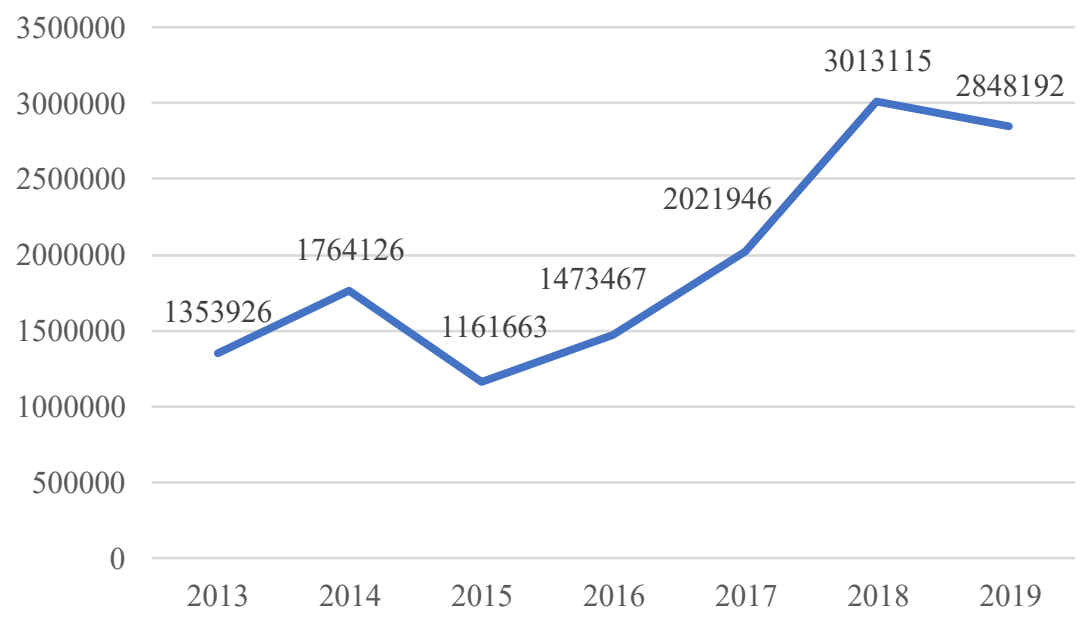

Fig. 2. The volume of housing mortgage lending provided by credit institutions to individuals in the Russian Federation, million rub.

In general, there is a trend towards active development of the mortgage lending market in the Russian Federation. However, it is necessary to note the negative impact on 
mortgages - the coronavirus epidemic. Against the backdrop of the coronavirus epidemic, the Russian mortgage market in 2020 was under pressure from a large number of negative factors. As a result, many banking organizations had to change the conditions for issuing a mortgage, introduce new systems for its payment, and also solve all other emerging problems associated with mortgage lending [6].

\section{Materials and Methods}

As of 01.01.2020, 1,269.3 thousand mortgage loans were issued in the Russian Federation, which is 5\% less than in 2018. From 2016 to 2015, there has been an annual increase in the number of issued mortgage loans (on average over four years, this growth was $17.5 \%$ ). The maximum number of mortgage loans was issued in 2018 (1.5 million units). 2019 is characterized by a decrease in the volume of issued mortgage loans by $14 \%$. Their volume in monetary terms reached 2.8 trillion rub. Record volume of issued mortgage loans exceeding 3 trillion. rub. observed in 2018. In addition, 2018 is characterized by the largest growth both in the volume of issued mortgage loans (by 35\%) and in their number (by $49 \%)$.

The weighted average rate on mortgage loans in 2019 reached its minimum (9\%). However, despite the active decrease in the weighted average rate in 2019 in the context of the monthly analysis, it is characterized by the level of rates higher than in 2018. Thus, as of April 1, 2019, the weighted average rate on mortgage lending reached the level of $10.4 \%$. The maximum level of the average weighted mortgage rate for the period under review is observed in $2014(13.16 \%)$, which is associated with a significant increase in the key rate.

Thus, it is possible to determine the relationship between two indicators, such as: the mortgage rate and the number of mortgages issued. Fig. 3 shows data broken down by monthly analysis for 2019 .

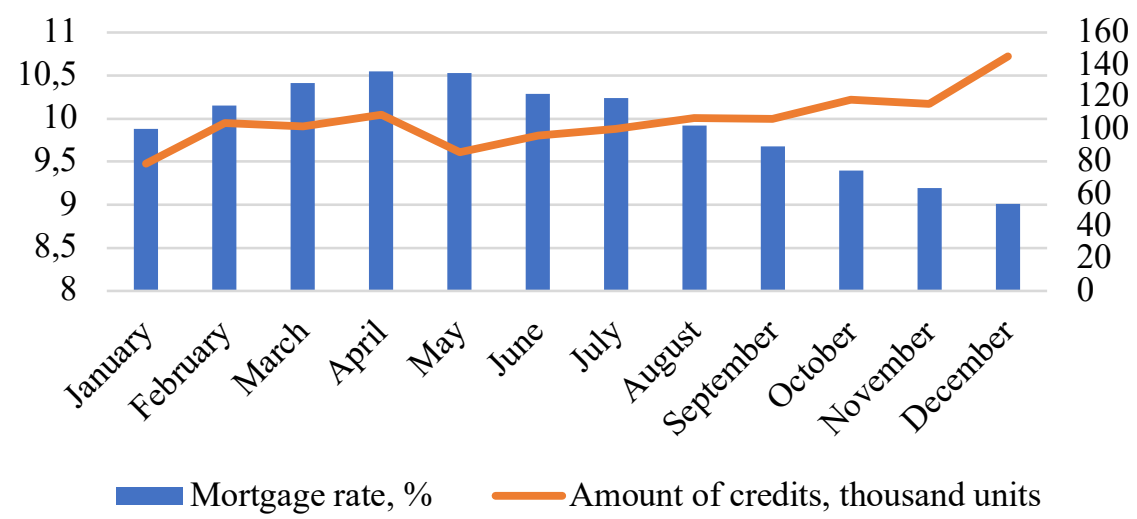

Fig. 3. Interdependence of the number of loans and the mortgage rate, 2019.

In May 2019, there is a sharp and significant reduction in the number of mortgage loans (by $21 \%$ ) from 108.9 thousand units. up to 85.9 thousand pcs. Just in the same month, the mortgage rate reached its maximum for the entire period of 2019 and amounted to $10.55 \%$. Further, there is a monthly decrease in mortgage rates and an increase in the number of mortgage loans. In December 2019, the largest number of mortgage loans was issued (145.2 thousand units) with a record low mortgage rate for the entire period of 2019, which amounted to $9 \%$. 
Mortgage lending is inextricably linked with the emergence of debt, incl. overdue, which negatively affects the performance of any credit institution.

Mortgage debt is growing every year. The growth in 2019 compared to 2014 was more than 2 times. At the end of 2019, the amount of debt amounted to RUB 7,470 billion. However, it is necessary to note the opposite trend in relation to mortgage loans issued in foreign currency. Debt in foreign currency is annually decreasing, its decrease in 2019 relative to 2014 was $85 \%$.

In 2019, the level of overdue debt on housing mortgage lending in the total amount of debt on mortgage loans has the lowest value (only 0.97), however, in 2015, the highest value of this indicator is observed $(1.66 \%)$. It should be noted that, despite the high value of overdue mortgage loans, this indicator corresponds to the limits recommended by scientists and economists (3-5\%). In general, after 2015, there has been a negative trend in the indicator under consideration, which is a positive trend $[7,8]$.

Also, the share of overdue debt on housing mortgage lending in the amount of debt on mortgage lending in rubles does not exceed $1-1.10 \%$, which is also in line with the recommendations. However, a completely opposite situation is observed with the share of overdue debt on mortgage lending, where the level of the studied indicator was $40.82 \%$ in 2019. Moreover, there is an annual increase in the share of overdue debt on mortgage lending in the total amount of debt on mortgage lending in foreign currency from $12.56 \%$ in 2014 to $34.46 \%$ in 2018 , and to $40.82 \%$ in 2019 . All this testifies to the increased credit risk when issuing mortgage loans in foreign currency.

It should be noted that despite the fact that the conditions of the coronavirus epidemic are difficult for most citizens of the Russian Federation, positive trends in the development of mortgage lending can be identified. To solve one of the problems in mortgage activities during the period of the coronavirus epidemic, which is caused by the reduction of jobs, conditions were introduced for mortgage vacations, the essence of which is that on their effect the banking organization reduces the financial burden on the borrower. In addition to mortgage vacations amid the coronavirus epidemic, the government approved a preferential mortgage program with a rate of $6.5 \%$ per annum. In general, it can be noted that mortgage lending in the Russian market has rather optimistic development forecasts [6].

\section{Results}

According to the ranking of the Rusipoteka Analytical Center, the top ten mortgage lending leaders in 2019 are as follows (Fig. 4). 


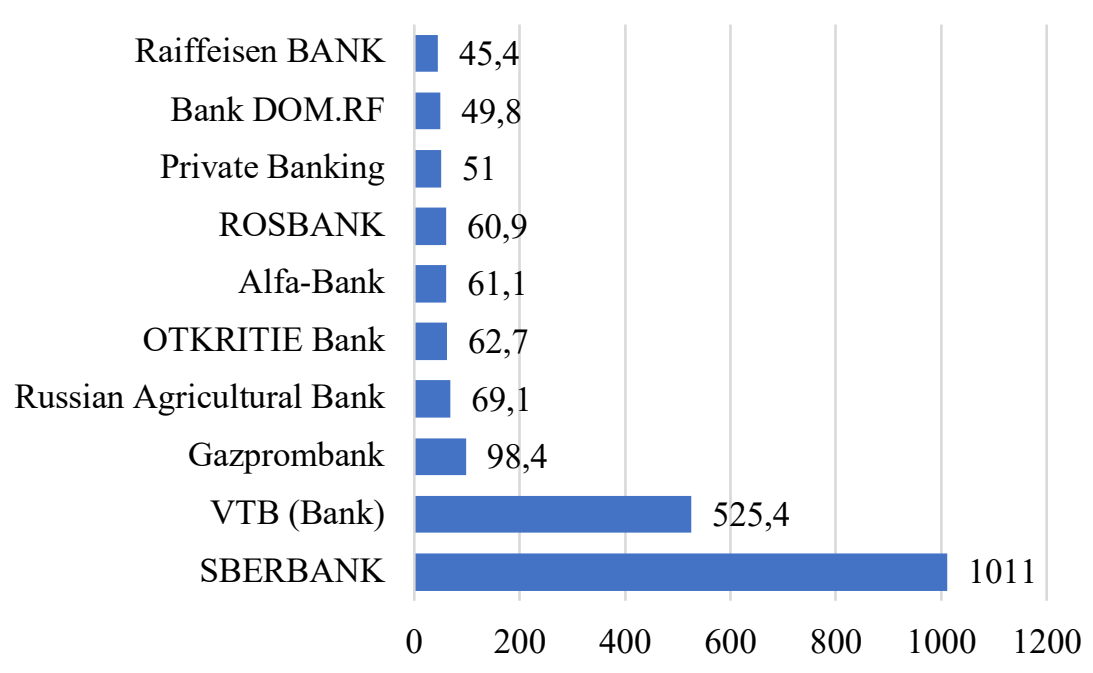

Fig. 4. Top ten mortgage lending leaders in Russia in 2019, billion rub.

The unchanged leader in mortgage lending is PJSC Sberbank. At the end of 2019, the bank issued 524 thousand mortgage loans for a total amount of 1,011 billion rubles. However, compared to the previous year, the volume of issued mortgage loans decreased by $35 \%$.

The indicators of Sberbank for mortgage lending significantly exceed those of the banks included in the top five (Fig. 5).

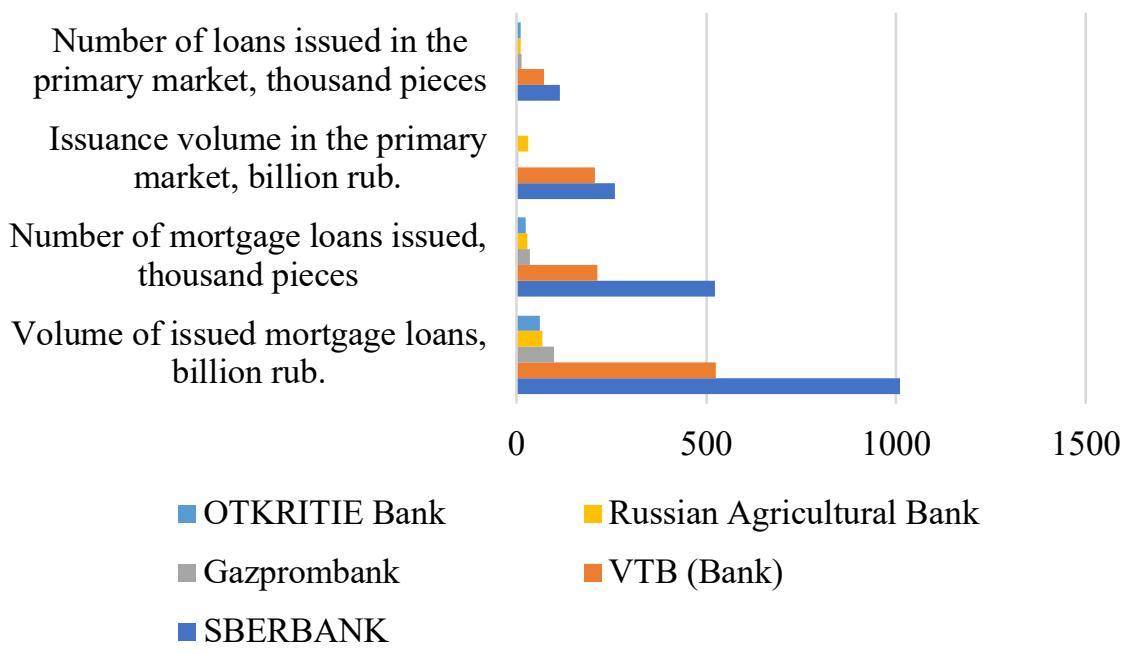

Fig. 5. Indicators of leading banks characterizing mortgage lending, 2020.

It should be noted that there has been a decrease in the quantitative indicators characterizing mortgage lending in the activities of Sberbank. The volume of issued mortgage loans and their number compared to 2018 decreased by $36 \%$. However, despite 
the decline in indicators characterizing mortgage lending, Sberbank remains the leader in the mortgage lending market, whose share in this segment is over $50 \%$.

The advantage of PJSC Sberbank in the mortgage lending market is that the bank provides mortgage loans with state support, which increases the confidence of borrowers in PJSC Sberbank as a lender, which contributes to the growth of its stability. The state program is aimed at issuing mortgage loans to certain categories of citizens.

\section{Discussion}

The main economic function of Sberbank is to provide lending services. Lending activities provide both an increase in the profit of a credit institution and an increase in public capital. Consequently, the activity of Sberbank in the field of mortgage lending contributes to the receipt of income not only at the bank level, but also at the society as a whole.

Since this line of business is the most profitable, then using the data of the accounting (financial) statements, we will determine the efficiency of Sberbank's credit operations in dynamics for 2017-2019.

The initial data for the calculation will be summarized in Table 1 [9].

Table 1. Dynamics of indicators characterizing the lending activities of Sberbank for 2017-2019.

\begin{tabular}{l|c|c|c}
\hline \multicolumn{1}{c}{ Indicators } & 2018 & 2019 & $\begin{array}{c}\text { Changes } \\
(2018-2019)\end{array}$ \\
\hline \multicolumn{2}{c}{ Initial data for calculation } \\
1. Income from loans provided, billion rub. & 1715,8 & 1727,7 & $-74,0$ \\
2. The cost of attracting resources, billion & 730,4 & 727,3 & $-150,9$ \\
rub. & 16843,9 & 18804,5 & $+2258,8$ \\
3. Average loan size, billion rub. & 22440,0 & 25029,5 & $+2815,5$ \\
4. Average assets, billion rub. & 61652,0 & 81883,8 & $-23309,6$ \\
5. The total amount of the bank's income, & & \\
billion rub. Estimated indicators & & \\
6. Profitability of credit operations per 1 & 7,65 & 6,90 & $-1,21$ \\
ruble of an asset, \% & 10,19 & 9,19 & $-1,7$ \\
7. Profitability of credit operations, \% & 2,35 & 2,38 & $+0,33$ \\
8. Profitability of credit operations, \% & 5,3 & $-0,3$ \\
9. Profitability of lending operations, \% & 5,9 & 5,3 \\
\hline
\end{tabular}

The data in the table indicate an increase in the rate of return on lending operations from $2.05 \%$ in 2017 to 2.38 in 2019, which indicates an increase in real profit received over the period.

The change also occurs in the profitability of credit operations per one ruble of the asset. In 2017, this indicator was $8.11 \%$, and in 2019 it decreased by 1.21 percentage points. and reached $6.9 \%$. This dynamics demonstrates a decrease in the volume of the bank's profit from credit operations for each ruble invested in active operations. The rate of profitability of credit operations for the period of the study is decreasing, which indicates that the bank receives less income from each ruble invested in credit operations. The profitability of the bank's lending operations over the period under study decreased from $5.6 \%$ in 2017 to $5.3 \%$ in 2019 .

Thus, the calculation of the indicators indicates that the lending activities of Sberbank are not without drawbacks, the solution of which will increase the efficiency of this business line [10]. 


\section{Conclusion}

The measures to achieve measures to improve the efficiency of mortgage lending development are:

- improving the pricing policy (reducing the interest rate on mortgage loans to the level of competitors);

- improvement of the mortgage lending program (introduction and improvement of existing mortgage lending programs for real estate objects (commercial mortgage), (introduce conditions that reduce the lending rate);

- improvement of information activities of the bank (expansion of advertising and information stands on mortgage lending, distribution of information sheets by mail to real customers and potential borrowers);

- improvement of mortgage loan refinancing (optimize refinancing processes and set competitive interest rates);

- improving the business processes of mortgage lending (accurate tracking of the processes of issuing and maintaining a loan. Timely effective decisions to eliminate the problems that have arisen. Modeling and control of the lending process).

Thus, the proposed measures will help improve the efficiency of mortgage lending, which should be developed based on available resource sources and not to the detriment of the achieved level. In general, it should be noted that the mortgage loan is promising, since it is the only driver of growth in the housing market and the main instrument of the availability of residential real estate for the population.

Also worth mentioning is the use of modern financial technologies, big data, artificial intelligence and cloud computing. The digital transformation of the economic space primarily covered the financial sector, in particular, credit institutions. It is in this direction that the range of services based on the use of innovative technologies and digital services for customers is increasing every year. Active digitalization of business is the most significant trend in modern banking. Digitalization of banking technologies is not just about the use of additional services in remote customer service, processing of data arrays, and the use of artificial intelligence technologies. Digitalization is, first of all, a strategic direction for the innovative development of the domestic banking sector. The banking sector is actively adopting digital technologies. The need to maintain a high level of competitiveness, maintain and expand the client base forces the financial market players to be constantly looking for new forms of service, among which the remote format is becoming more widespread.

In conditions of serious competition, the expansion of the circle of customers is inextricably linked with the constant search for new forms of their service. Commercial banks are the main financial intermediaries, the effectiveness of which directly reflects the degree of development of the financial market. Currently, banks are faced with the task of making the shortest possible period of time that arises between the client's need and the ability to satisfy his demand. To solve this problem, banks began to practice remote banking services, which are available in a 24/7 format.

Experts note that digital transformation is accompanied by a colossal increase in the amount of information [11, 12]. In these conditions, the policy of active implementation of technological innovations is a factor in maintaining and increasing competitiveness in the banking services sector. Thus, the promotion of innovations caused by the new wave of scientific and technological progress is most progressing in the financial environment. Innovations in the banking sector are represented not only by technical and technological innovations. Innovations are associated with the introduction of new forms of business organization, the spread of new digital products and services. Large banks have great potential for investing in modern financial technologies, carrying out digital transformation, 
in comparison with small and even medium-sized participants in financial and credit relations. The competition between brands in the struggle to expand the customer base is replaced by competition in the consumer characteristics of products and services. Digital transformation, therefore, is the application of advanced digital technologies based on changing the parameters and properties of produced goods and services, obtaining new market opportunities.

Currently, the level of competitiveness of financial organizations is determined by the ability to implement and use modern digital technologies $[13,14]$. In the digital transformation of the banking environment, the following development vectors can be distinguished - the emergence of Digital-channels, Digital-products, the creation of a full cycle of digital services, the creation of Digital-brain. The need to understand the needs of the client and study his behavior is the most important direction of digital transformation. Only with this approach will banks be able to adapt to the changing consumer culture in order to remain efficient in the future.

\section{References}

1. V. V. Bredihin, N.P. Kazarenkova, R.I. Fedosova, Problems and Prospects for the Development of Mortgage Lending in the Russian Economy, Izvestiya Southwest State University, 3 (66), 120-129 (2016)

2. T. Kolmykova, E. Merzlyakova, Human role in the modern robotic reproduction development, Economic Annals-XXI, 180 (11-12), 183-190 (2019)

3. T. Kolmykova, E. Merzlyakova, B. Preobrazhensky, N. Serebryakova, Problems of investment support for innovative development, The 33rd International Business Information Management Association Conference, IBIMA «Education Excellence and Innovation Management through Vision 2020», 2199-2204 (2019)

4. E. V. Sitnikova, T. S. Kolmykova, E. O. Astapenko, E. A. Grivachev, An Assessment of Commercial Banks' Financial Sustainability, Lecture Notes in Networks and Systems, 115, 370-378 (2020)

5. I. N. Tretyakova, E. V. Sitnikova, The industrial complex of the region: lending trends and development prospects (based on materials from the Kursk region), Education. Science. Scientific staff, 1, 141-144 (2015)

6. M. A. Gricenko, A. V. Drozdova, Mortgage lending: current state and development prospects in the context of the coronavirus epidemic, Economy and business: theory and practice, 5-2 (63), 25-30 (2020)

7. N. Kazarenkova, T. Kolmykova, Modern Growth Points of the Russian Banking Sector and Their Impact on Economic Development of the Country, Journal of Applied Economic Sciences, XII, 985-995 (2017)

8. T. Kolmykova, N. Kazarenkova, International criteria for the country's banking system efficiency assessment, Economic Annals-XXI, 157 (3-4 (1)), 97-99 (2016)

9. The Central Bank of the Russian Federation. Access mode: http: // www.cbr.ru

10. I. Tretyakova, E. Sitnikova, International financial processes influence on the retail lending market in Russia development, Економічний часопис-XXI, 3-4-1 (157), 100102 (2016)

11. R. A. Atun, I. Harvey, J. Wild, Innovation, patents and economic growth, International Journal of Innovation Management, 11 (2), 279-297 (2007)

12. A. G. Hu, I. Png, Patent rights and economic growth: evidence from cross-country panels of manufacturing industries, Oxford Economic Papers, 65 (3), 675-698 (2013) 
13. A. Joyce, R.L. Paquin, The triple layered business model canvas: a tool to design more sustainable business models, Journal of Cleaner Production, 135, 1474-1486 (2016)

14. S. Schaltegger, M. Beckmann, E. Hansen, Transdisciplinarity in corporate sustainability. Mapping the field, Business Strategy and the Environment, 22, 219-229 (2013) 